\title{
PENINGKATKAN EFEKTIVITAS PEMBELAJARAN IPA BERVISI SETS \\ DENGAN PENDEKATAN SAVI UNTUK PEMBENTUKAN KARAKTER \\ PESERTA DIDIK SEKOLAH DASAR NEGERI SADENG 03.
}

\author{
Bayu Wijayama \\ Guru SD Negeri Sadeng 03 Kota Semarang \\ bayuwijayama@gmail.com
}

\begin{abstract}
Abstrak
Tujuan penelitian adalah untuk meningkatkan efektifitas, karakter peduli lingkungan, rasa ingin tahu dan disiplin dalam pembelajaran IPA bervisi SETS dengan pendekatan SAVI. Penelitian ini adalah Penelitian Tindakan Kelas yang dimulai dari 1) perencanaan tindakan (planning), 2) penerapan tindakan (action), 3) pengamaatan (observing) 4) refleksi mengevaluasi proses dan hasil tindakan (reflecting). Kegiatan penelitian dilaksanakan dalam dua siklus. Perencanaan pembelajaran dimulai dengan membuat perangkat Silabus, RPP, LKPD dan soal. Hasil penelitian pembelajaran IPA bervisi SETS dengan pendekatan SAVI efektif dapat meningkatkan hasil belajar peserta didik secara klasikal pada materi sistem pernafasan manusia. Data hasil penelitian menunjukkan peningkatan prosentase dari kegiatan pra siklus 54,8\% kemudian di siklus I menjadi $77,4 \%$ dan di siklus II prosentase sebesar $80,6 \%$. Hasil analisis karakter peduli lingkungan dengan skor 3,5, rasa ingin tahu dengan skor 3,44 dan karakter disiplin dengan skor 3,5 sudah melebihi indikator keberhasilan penelitian dengan Skor Akhir Sa $3,25<$ skor $\leq 4$ ketuntasan klasikal $\geq 75 \%$ pada kriteria membudaya (MK) dengan demikian penelitian berhasil meningkatkan karakter peduli lingkungan, rasa ingin tahu dan disiplin.
\end{abstract}

Kata Kunci: pembelajaran ipa, visi sets, pendekatan savi, karakter

\begin{abstract}
The purpose of this research is to improve the effectivity, environmental care character, curiosity and discipline in science subject with SETS using SAVI approach. This research is an action research, and starts from 1) the action planning (planning), 2) the implementation of the action (action), 3) observing 4) reflecting of process evaluation and action result (reflecting). This research conducted in two cycles. Planning of learning begins with making syllabus, lesson plans, LKPD and question material. The result of learning science with SETS using SAVI approach can improve the learning result of students classically in chapter human respiration system. Research data shows an increase
\end{abstract}


in the percentage of pre-cycle activity $54.8 \%$ then in first cycle $77.4 \%$ and in second cycle $80.6 \%$. The analysis results of environmental care character score 3.5, the curiosity score 3.44 and character discipline score 3.5 has exceeded the sccess indicator of research with final score Sa $3.25<$ score $\leq 4$ classical completeness $\geq 75 \%$ on criteria entrenched $(M K)$ thus this research is success to increase the environmental care character, curiosity and discipline.

Keywords: science learning, sets vision, savi approach, character

\section{A. PENDAhUluAN}

Tujuan pembelajaran IPA di Sekolah Dasar (SD) seperti diamanatkan dalam kurikulum KTSP tidaklah hanya sekedar peserta didik memiliki pemahaman tentang alam semesta saja, melainkan melalui pendidikan IPA peserta didik juga diharapkan: (1) mengembangkan pengetahuan dan pemahaman konsep-konsep IPA yang bermanfaat dan dapat diterapkan dalam kehidupan sehari-hari, (2) mengembangkan rasa ingin tahu, sikap positif dan kesadaran tentang adanya hubungan yang saling mempengaruhi keterampilan proses untuk menyelidiki alam sekitar, memecahkan masalah dan membuat keputusan, (3) meningkatkan kesadaran untuk berperan serta dalam memelihara, menjaga dan melestarikan lingkungan alam. ${ }^{1}$

IPA merupakan salah satu mata pelajaran di SD yang di dalamnya terintegrasi pendidikan karakter yaitu di antaranya rasa ingin tahu, peduli lingkungan dan disiplin. Karakter sebagai watak, tabiat, akhlak, atau kepribadian seseorang yang terbentuk dari hasil internalisasi berbagai kebajikan (virtues) yang diyakini dan digunakan sebagai landasan untuk cara pandang, berpikir, bersikap, dan bertindak. $^{2}$ Kebajikan terdiri atas sejumlah nilai, moral, dan norma, seperti jujur, berani bertindak, dapat dipercaya, dan hormat kepada orang lain. Pembelajaran IPA di SD jika

1 Sri Sulistyorini, Pengembangan IPA Sekolah Dasar, (Yogyakarta: Tiara Karya, 2007), hlm.42.

2 H Hasan, S, Pengembangan Pendidikan Budaya dan Karakter Bangsa, (Kementrian Pendidikan Nasional Balitbang Puskur, 2010), hlm.3. 
dikaitkan dengan pendidikan karakter tidak hanya transfer ilmu dari guru ke peserta didik melainkan adanya keterlibatan peserta didik dalam proses pembelajaran. Paradigma guru sebagai sumber ilmu sudah tidak lagi diberlakukan diera modern ini. Peralihan cara mengajar teacher centered ke students centered adalah cara yang terbaik untuk mencapai tujuan pembelajaran IPA di SD. Pembelajaran IPA yang di berikan di SD haruslah mencakup semua sesuai dengan tujuan IPA yaitu meningkatkan kesadaran untuk berperan serta dalam memelihara, menjaga dan melestarikan lingkungan alam.

Pembelajaran IPA yang di berikan di SD haruslah mencakup semua sesuai dengan tujuan IPA yaitu meningkatkan kesadaran untuk berperan serta dalam memelihara, menjaga dan melestarikan lingkungan alam. Hasil pengamatan di SDN Negeri 03 Sadeng Kota Semarang menunjukkan nilai rata-rata ulangan harian 1-4 tahun pelajaran 2011/2012 berturut-turut menunjukkan nilai 54,8; 57,7; 58,5 dan 65,0. Data hasil ulangan harian tersebut terdapat tiga rata-rata yang di bawah Kriteria Ketuntasan Minimal (KKM) yaitu 62. Kelemahan pembelajaran IPA selama ini adalah bahwa pembelajaran tersebut lebih menekankan pada penguasaan sejumlah fakta dan konsep, dan kurang memfasilitasi peserta didik agar memiliki hasil belajar yang comprehensive tidak hanya kognitif saja tetapi afektif dan psikomotorik. Pembelajaran IPA sering dilaksanakan dalam bentuk latihanlatihan penyelesaian soal-soal tes, semata-mata dalam rangka mencapai target nilai tes tertulis evaluasi hasil belajar sebagai ukuran utama prestasi peserta didik dan kesuksesan guru dalam mengelola pembelajaran.

Pembelajaran IPA diperlukan dalam kehidupan sehari-hari untuk memenuhi kebutuhan manusia melalui pemecahan masalah-masalah yang dapat diidentifikasikan. Penerapan IPA perlu dilakukan secara bijaksana agar tidak berdampak buruk terhadap lingkungan. Di tingkat SD/MI diharapkan ada penekanan pembelajaran Salingtemas (Sains, lingkungan, 
teknologi, dan masyarakat) atau SETS yang diarahkan pada pengalaman belajar untuk merancang dan membuat suatu karya melalui penerapan konsep IPA dan kompetensi bekerja ilmiah secara bijaksana. Implikasi visi SETS Praksis pembelajaran bervisi dan berpendekatan SETS itu bila dilaksanakan dengan sungguh-sungguh tentu akan memberi keuntungan bagi berbagai pihak, para peserta didik itu sendiri, pendidik, dan masyarakat. ${ }^{3}$ Pembelajaran dengan menggunakan perangkat pembelajaran yang dikembangkan efektif untuk membelajarkan kebencanaan alam dan sains. Hal ini dapat dilihat dari ketuntasan hasil belajar di setiap akhir pembelajaran, serta peningkatan pemahaman terhadap sains dan kebencanaan alam. ${ }^{4}$

Pendekatan pembelajaran yang diterapkan sebaiknya pendekatan yang komperehensif yaitu dengan mencakup ranah kognitif, afektif maupun psikomotorik. Salah satu pendekatan yang mencakup ketiga ranah tersedut adalah pendekatan Somatic Auditory Visualization dan Intelectually (SAVI). Pendekatan SAVI mempercepat dan meningkatkan hasil belajar, menciptakan lingkungan belajar yang lebih sehat, membangun masyarakat belajar yang efektif dan memanusiakan kembali proses belajar. ${ }^{5}$ Hasil penelitian yang sejalan dengan pendapat Meier menyimpulkan perangkat pembelajaran berdasar masalah dengan pendekatan SAVI valid dan reliable, dapat meningkatkan keterampilan memecahkan dan dapat meningkatkan keterampilan.

3 A. Binadja. Penerapan Visi SETS Dalam Pengembangan Kurikulum dan Implikasinya, Makalah disajikan pada In House Training, SMA Negeri 4 Semarang. Semarang 10-11 Juli 2006.

${ }^{4}$ A. Rusilowati, Mitigasi Bencana Alam Bebasis Pembelajaran Kebencanaan Alam Bervisi Science Environment And Society Terintegrasi Dalam Beberapa Mata Pelajaran, Laporan Penelitian, Semarang: Pendidikan Fisika FMIPAUnnes, 2009.

${ }^{5}$ D, Meier, The Accelerated Learning Handbook Panduan Kreatif dan Efektif Merancang Program Pendidikan dan Pelatihan, Transleted by Astuti, Rahmani. 2003, (Bandung: Kaifa, 2002). 
Permasalahan dalam penelitian ini adalah: (1) bagaimana karakteristik perangkat pembelajaran IPA bervisi SETS dengan pendekatan SAVI, (2) bagaimana kevalidan perangkat pembelajaran IPA bervisi SETS dengan pendekatan SAVI, (3) bagaimana keefektifan perangkat pembelajaran IPA bervisi SETS dengan pendekatan SAVI, (4) bagaimana kepraktisan perangkat pembelajaran IPA bervisi SETS dengan pendekatan SAVI.

Tujuan yang ingin dicapai oleh peneliti dari penelitian ini adalah: (1) menghasilkan perangkat pembelajaran IPA bervisi SETS dengan pendekatan SAVI yang terdiri dari Silabus, Rencana Pelaksanaan Pembelajaran (RPP), Lembar kerja Peserta didik (LKPD) Bahan ajar, Soal tes hasil belajar, CD Pembelajaran yang bermuatan karakter rasa ingin tahu, peduli lingkungan dan disiplin, (2) menghasilkan perangkat pembelajaran IPA bervisi SETS dengan pendekatan SAVI yang valid, (3) mengetahui keefektifan pembelajaran IPA SD dengan menggunakan perangkat pembelajaran IPA bervisi SETS dengan pendekatan SAVI, (4) mengetahui kepraktisan pembelajaran IPA SD dengan menggunakan perangkat pembelajaran IPA bervisi SETS dengan pendekatan SAVI.

\section{B. METODE PENELITIAN}

Penelitian ini adalah Penelitian Tindakan Kelas (PTK) terdiri dari dua siklus yang dimulai dari 1) perencanaan tindakan (planning), 2) penerapan tindakan (action), 3) pengamaatan (observing) 4) refleksi mengevaluasi proses dan hasil tindakan (reflecting), yang dilaksanakan dari bulan September sampai November 2012. Penelitian dilakukan di SDN Sadeng 03 karena peneliti mengajar di SDN Sadeng 03 tahun pelajaran 2012/2013 di kelas $\mathrm{V}$ berada di jalan Jogoprono kelurahan Sadeng Kecamatan Gunungpati Kota Semarang. Subyek penelitian adalah peserta didik kelas V 
SDN Sadeng 03 yang berjumlah 31 yang terdiri dari 18 laki-laki dan 13 perempuan.

Sumber data yang dipakai dalam pengumpulan data adalah siswa kelas V SDN Sadeng 03 yang berjumlah 31, guru dan dokumen. Jenis data yang didapatkan adalah; 1) data hasil belajar peserta didik dan 2) data karakter peduli lingkungan, rasa ingin tahu dan disipin. Teknik pengumpulan data pada penelitian ini dengan menggunakan teknik tes dan non tes. Teknik tes dengan memberikan lima soal uraian sedangkan teknik non tes dengan mengggunakan lembar observasi penilaian karakter peserta didik.

Teknik analisis data menggunakan teknik analisis statistik deskriptif. Data kuantitatif yang dianalisis dengan teknik analisis statistik deskriptif. Dari penyajian data bentuk persentase diambil kesimpulan tentang masing-masing indikator berdasarkan kriteria yang telah ditetapkan. Kelas disebut tuntas belajar jika telah terdapat 75\% yang telah mencapai skor minimal. ${ }^{6}$ Berdasarkan kriteria ketuntasan belajar maka dapat dikategarikan menjadi dua, yaitu tuntas dan tidak tuntas. Kriteria ketuntasan dapat dilihat pada Tabel 1.

Tabel 1. Klasifikasi ketuntasan dalam persentase

\begin{tabular}{cl}
\hline Prestasi belajar (\%) & Kualifikasi \\
\hline $75 \%-100 \%$ & Tuntas \\
$50 \%-75 \%$ & Cukup \\
$25 \%-50 \%$ & Rendah \\
$0,0 \%-25 \%$ & Sangat rendah \\
\hline
\end{tabular}

${ }^{6}$ Buku I, Depdiknas, Manajemen Peningkatan Mutu Pendidikan Berbasis Sekolah, (Jakarta: Depdiknas, 2001), hlm. 37. 
Instrument yang digunakan untuk mengamati karakter peduli lingkungan, rasa ingin tahu dan disiplin adalah lembar pengamatan berupa rating scale. Adapun kriteria untuk mengukur karakter peserta didik dapat dilihat pada Tabel 2 .

Tabel 2. Kriteria Pengamatan Karakter

\begin{tabular}{ll}
\hline \multicolumn{1}{c}{ Kriteria } & \multicolumn{1}{c}{ Skor } \\
\hline Membudaya (MK) & $3,25<$ skor $\leq 4$ \\
Mulai Berkembang (MB) & $2,5<$ skor $\leq 3,25$ \\
Mulai Terlihat (MT) & $1,75<$ skor $\leq 2,5$ \\
Belum Terlihat (BT) & $1,00<$ skor $\leq 1,75$ \\
\hline
\end{tabular}

Validitas instrumen soal tes kognitif sebelum digunakan di validasi dengan validitas isi (content validity) oleh teman sejawat. Instrument yang berbentuk test, pengujian validitas isi dapat dilakukan dengan membandingkan antara isi instrument dengan materi pelajaran yang telah diajarkan7. Teman sejawat memvalidasi lembar pengamatan karakter dengan melihat kisi-kisi instrument dan lembar pengamatan karakter peduli lingkungan, rasa ingin tahu dan disiplin. Teknik analisis data dalam penelitian ini adalah static deskriptif yaitu mendeskripsikan data yang telah terkumpul untuk membuat kesimpulan.

Indikator kinerja dalam penelitian ini adalah (1) Pembelajaran IPA materi system pernafasan manusia efektif, yakni peserta didik berhasil meningkatkan hasil belajar kognitif sesuai kriteria ketuntasan belajar minimum klasikal $>75 \%$ di atas nilai KKM yaitu 65. (2) Karakter peduli linkungan, rasa ingin tahu, dan disiplin dengan Skor Akhir Sa 3,25< skor $\leq$ 4 ketuntasan klasikal $\geq 75 \%$ pada kriteria membudaya.

\footnotetext{
${ }^{7}$ Sugiyono, Metode Penelitian Pendidikan, (Bandung: Alfabeta, 2010), hlm.
} 182. 


\section{HASIL PENELITIAN DAN PEMBAHASANNYA}

\section{Hasil Penelitian}

Pengambilan data awal dilakukan dengan teknik dokumentasi yaitu mencari informasi dari dokumen daftar nilai kelas yang digunakan pada tahun pelajaran 2011/2013. Kondisi awal hasil belajar IPA sebelum penelitian didapat dari nilai UKK semester genap tahun 2011/2012 dan peneliti memberikan soal tes kepada peserta didik kelas V SDN Sadeng 03. Hasil UKK menunjukkan rata-rata 60 dengan nilai tertinggi 82 dan nilai terendah 40. Hasil ukk tersebut masih dikatakan belum tuntas Karen prosentase ketuntasan klasikalnya hanya 51,6\%. Perolehan nilai UKK tidak berbeda jauh dengan perolehan nilai pra siklus yang menunjukkan ratarata nilai 66 dengan nilai tertinggi 90 dan nilai terendah 40. Berikut adalah visualisasi dari kondisi awal hasil belajar IPA di SDN Sadeng 03 yang ditunjukkan pada Gambar 1.
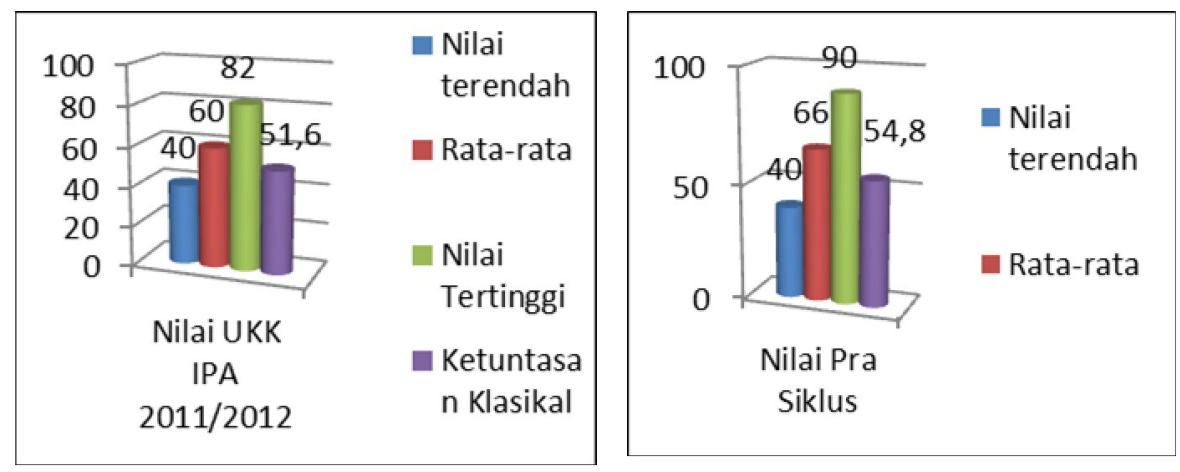

Gambar 1. Kondisi awal hasil belajar peserta didik

Pengamatan kondisi awal karakter dilakukan ketika kegiatan pra siklus menggunakan lembar pengamatan karakter menunjukkan skor ratarata karakter peduli lingkungan 2.47 dengan kriteria Mulai Terlihat (MT), karakter rasa ingin tahu 2,68 dengan kriteria Mulai Berkembang (MB) dan karakter disiplin 2,16 dengan kriteria Mulai Terlihat (MT). 
a. Deskripsi Hasil Siklus I

Tahap perencanaan peneliti menyusun perangkat pembelajaran berupa Silabus, RPP, LKPD dan instrumen soal dan lembar pengamatan karakter. Instrumen soal dan lembar pengamatan di validasi oleh teman sejawat. Hasil validasi menunjukkan skor 3,25 $\leq$ skor $\leq 4$ yang berarti instrumen soal sangat baik, sehingga dapat dipakai dengan sedikit revisi. Instrumen lembar pengamatan karakter peduli lingkungan, rasa ingin tahu dan disiplin di validasi dengan cara menganalisa kisi-kisi instrument dan lembar pengamatan karakter.

Tindakan (action) dilaksanakan pada hari Senin, 17 September 2012. Alur kegiatannya adalah sebagai berikut: 1) kegiatan Pendahuluan (10 menit) mengajukan pertanyaan kepada peserta didik: “Anak- anak apa yang kita lakukan setiap saat?" kemudian guru mendengarkan pendapat dari berbagai peserta didik dan menindaklanjuti jawaban dengan bertanya kembali "Apakah manusia dapat hidup jika tidak bernafas?" Motivasi, yaitu; a) guru meminta peserta didik untuk peduli terhadap lingkungan, disiplin dan memiliki rasa ingin tahu yang tinggi, b) manfaat mempelajari sistem pernafasan manusia adalah mengetahui alat pernafasan manusia. Menyampaikan tujuan pembelajaran "Anak-anak hari ini kita akan mempelajari tentang sistem pernafasan manusia". Menyampaikan cakupan materi dan penjelasan uraian kegiatan sesuai silabus, yaitu: kegiatan pembelajaran secara berkelompok dengan menggunakan visi SETS dan pendekatan SAVI dengan membiasakan sikap peduli lingkungan, rasa ingin tahu dan disiplin.

Kegiatan inti terdiri dari eksplorasi, elaborasi dan konfirmasi. Rincian Kegiatan eksplorasi adalah: a) guru membagi peserta didik menjadi empat kelompok, b) peserta didik diminta untuk melakukan aktivitas menghirup udara, menahan dan mengeluarkannya (Somatic), 
c) peserta didik mengidentifikasi kegiatan yang baru saja dilakukannya, d) peserta didik melalui CD Pembelajaran mencari informasi tentang sistem pernafasan manusia (Auditory-Visualization), e) peserta didik diminta untuk mengidentifikasi sistem pernafasan manusia melalui sumber bacaan lain, f) peserta didik diberi lembar kerja (LKPD) dengan visi SETS.

Kegiatan elaborasi terdiri dari; a) peserta didik melalui LKPD mendiskusikan sistem pernafasan manusia, b) peserta didik melalui LKPD mendiskusikan organ pada saluran pernapasan manusia dan fungsinya, c) peserta didik menyiapkan alat dan bahan membuat model pernafasan manusia, d) peserta didik dalam kelompok menyiapkan model pernafasan manusia (Somatic), e) peserta didik melalui LKPD mendiskusikan model sistem pernafasan manusia dalam konteks Science, Environment, Technology and Society (SETS), f) peserta didik diminta untuk membuat peta konsep sistem pernafasan manusia (Intellectually), g) peserta didik diminta untuk mempersiapkan pertanyaan untuk ditanyakan pada kelompok lain yang presentasi hasil diskusi dan $\mathrm{h}$ ) peserta didik dalam kelompok mempresentasikan hasil diskusi kelompok.

Rincian kegiatan konfirmasi, yaitu; a) guru dan peserta didik memberikan pertanyaan kepada kelompok yang mempresentasikan hasil diskusi. b) peserta didik memberikan umpan balik terhadap pertanyaan yang disampaikan dalam diskusi dan presentasi, Kegiatan penutup guru memberikan umpan balik dengan cara menyimpulkan materi pembelajaran, memberikan evaluasi dan memberikan tindak lanjut berupa pengayaan dan remidi.

b. Efektivitas Pembelajaran (Hasil Belajar)

Efektivitas belajar dalam penelitian ini adalah hasil belajar kognitif yang diperoleh dari instrument soal sebagai evaluasi di setiap 
akhir siklus. Perolehan nilai pada Siklus I menunjukkan hasil belajar kognitif dengan rata-rata 75.2, nilai terendah 50, nilai tertinggi 100 dan dari 31 peserta didik yang memperoleh nilai di atas KKM sebanyak 24 dengan prosentase ketuntasan klasikal 77.4 \% dalam kategori tuntas. Lebih jelasnya hasil belajar di siklus I dapat dilihat pada Gambar 2.

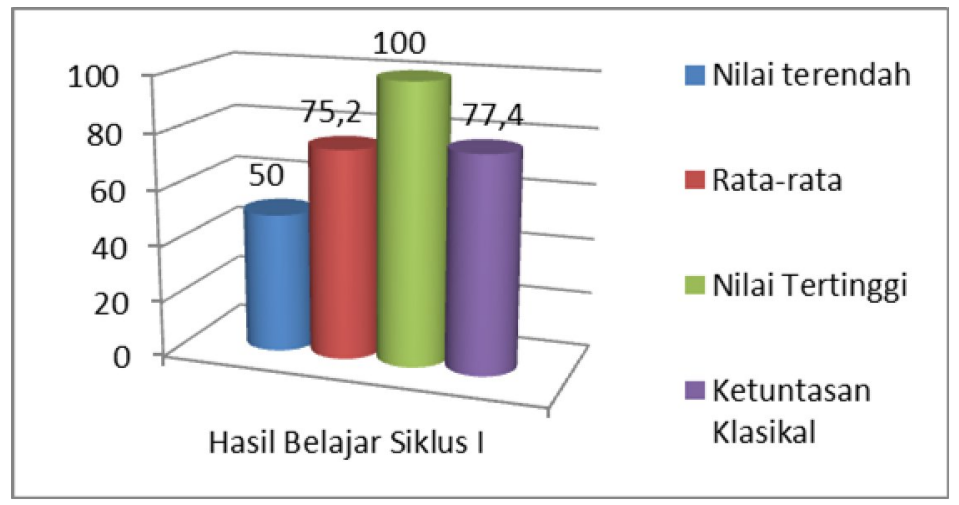

Gambar 2. Hasil belajar Siklus I

c. Hasil pengamatan karakter

Karakter peduli lingkungan memperoleh skor 3,36 dengan kriteria Membudaya (MK), karakter rasa ingin tahu memperoleh skor 3.37 dengan kriteria Membudaya (MK) dan karakter disiplin memperoleh skor 3.5 dengan kriteria Membudaya (MK).

Hasil pengamatan di atas menunjukkan bahwa pembelajaran yang dilaksanakan pada Siklus I sudah meningkatkan efektifvitas belajar dan karakter peduli lingkungan, rasa ingin tahu dan disiplin. Perbandingan perolehan nilai pra siklus dan siklus I dapat di lihat pada Tabel 3.

Tabel 3. Perbandingan hasil belajar dan karakter pra siklus dengan siklus I 


\begin{tabular}{|c|c|c|c|c|c|c|}
\hline \multirow{2}{*}{ Siklus } & \multirow{2}{*}{$\begin{array}{c}\text { Hasil } \\
\text { Belajar }\end{array}$} & \multirow{2}{*}{$\begin{array}{l}\text { Kriteri } \\
\quad \text { a }\end{array}$} & \multicolumn{3}{|c|}{ Karakter } & \multirow{2}{*}{ Kriteria } \\
\hline & & & 1.1 & 1.2 & 1.3 & \\
\hline Pra siklus & $54,8 \%$ & BT & 2,47 & 2,68 & 2,16 & $\begin{array}{c}\text { MB, MB, } \\
\text { MT }\end{array}$ \\
\hline Siklus I & $77,4 \%$ & TT & 3,36 & 3,37 & 3,22 & $\begin{array}{c}\mathrm{MK}, \mathrm{MK}, \\
\mathrm{MB}\end{array}$ \\
\hline
\end{tabular}

Keterangan: 1.1 Peduli lingkungan, 1.2 Rasa ingin tahu,, 1.3 Disiplin

Tabel 3. menunjukkan bahwa pembelajaran IPA bervisi SETS dengan pendekatan SAVI mengalami peningkatan. Adapun penjelasannya adalah sebagai berikut: 1) Peningkatan hasil belajar yaitu sebesar 22,6\% dari ketuntasan di pra siklus sebesar 54,8\% dengan kriteria Belum Tuntas (BT) menjadi 77,4\% di siklus I dengan kriteria Tuntas (TT). 2) Peningkatan karakter peduli lingkungan dari skor awal di kegiatan pra siklus 2,47 dengan kriteria Mulai Berkembang (MB) menjadi 3,36 dengan kriteria membudaya (MK) di siklus I yang berarti mengalami peningkatan sebesar 0,89. 3) Peningkatan karakter rasa ingin tahu sebesar 0,69 dari skor awal pra siklus 2,68 dengan kriteria Mulai Berkembang (MB) menjadi 3,37 dengan kriteria Membudaya (MK), 4) Peningkatan karakter disiplin sebesar 1,06 dari skor awal 2,16 dengan kriteria Mulai Terlihat (MT) menjadi 3,22 dengan kriteria Mulai Berkembang (MB). Kegiatan pembelajaran di siklus I masih ada peningkatan nilai karakter disiplin yang belum mencapai katagori Membudaya (MK). Hasil refleksi dijadikan bahan masukan dan didiskusikan dengan kolaborator/teman sejawat untuk tahapan perencanaan di siklus II.

d. Deskripsi hasil siklus II 
Perencanaan di siklus II didasarkan pad a hasil refleksi di siklus I. kperencanaan dimulai dengan membuat perangkat pembelajaran berupa Silabus, RPP, LKPD, Soal evaluasi dan mempersiapkan instrument. Seluruh perangkat pembelajaran di validasikan oleh teman sejawat sebagai kolabirator.hasil yang validasi soal menunjukkan instrument dapat digunakan pada kegiatan di siklus II.

Tindakan (action) dilaksanakan pada hari Senin, 8 Oktober 2012. Alur kegiatannya adalah sebagai berikut: Kegiatan Pendahuluan (10 menit) dengan mengajukan pertanyaan kepada peserta "Siapa yamg pergi ke kolam renang ketika liburan?". "Pernahkah kalian menyelam ke dasar kolam renang?”. "Apa yang dirasakan ketika berada didasar kolam renang?" Guru memberikan motivasi kepada peserta didik, yaitu; a) guru meminta peserta didik untuk peduli terhadap lingkungan, disiplin dan memiliki rasa ingin tahu yang tinggi, b) guru memotivasi peserta didik bahwa pentingnya mempelajari fungsi alat pernafasan dan hasilnya. Menyampaikan tujuan pembelajaran "Anakanak hari ini kita akan mempelajari fungsi alat pernafasan dan membuktikan hasil dari pernafasan manusia", Menyampaikan cakupan materi dan penjelasan uraian kegiatan sesuai silabus.

Kegiatan pembelajaran secara berkelompok dengan menggunakan visi SETS dan pendekatan SAVI dengan membiasakan sikap peduli lingkungan, rasa ingin tahu dan disiplin. Kegiatan inti pada tahap eksplorasi kegiatannya adalah; a) guru membagi peserta didik menjadi empat kelompok, b) peserta didik diminta mencari informasi terjadinya daur air (rasa ingin tahu), c) peserta didik melalui CD Pembelajaran mencari informasi tentang fungsi alat pernafasan dan membuktikan oksigen dan karbondioksida dalam bernafas (AuditoryVisualization), d) peserta didik mengidentifikasi fungsi dari organ 
pernafasan manusia, e) peserta didik diberi lembar kerja (LKPD) dengan visi SETS.

Tahap elaborasi kegiatannya sebagai berikut; a) peserta didik melalui LKPD menyusun langkah-langkah percobaan sederhana membuktikan uap air dan karbondioksida dalam pernafasan (Somatic), b) peserta didik dengan tertib mengikuti aturan pelaksanaan kegiatan percobaan membuktikan uap air dan karbondioksida dalam pernafasan (disiplin), c) peserta didik dalam kelompok melaksanakan kegiatan percobaan sederhana membuktikan uap air dan karbondioksida dalam pernafasan, d) peserta didik melalui LKPD mendiskusikan hasil percobaan membuktikan uap air dan karbondioksida dalam pernafasan, e) peserta didik menganalisa permasalahan percobaan membuktikan uap air dan karbondioksida dalam pernafasan menggunakan diagram SETS (Intellectually), f) peserta didik dalam kelompok secara bergantian mempresentasikan hasil diskusi kelompok (auditory), g) guru dan peserta didik memberikan pertanyaan kepada kelompok yang mempresentasikan hasil diskusi.

Tahap konfirmasi kegiatannya adalah; a) peserta didik memberikan umpan balik terhadap pertanyaan yang disampaikan dalam diskusi dan presentasi, dan b) peserta didik diminta untuk membuat peta konsep mengenai fungsi organ pernafasan manusia (Intellectually)

Urutan kegiatan penutup adalah; a) guru memberikan umpan balik, b) guru bersama peserta didik menyimpulkan materi pembelajaran, c) guru memberikan evaluasi, d) guru memberikan tidak lanjut berupa pengayaan dan remidi, e) guru meminta peserta didik merapikan tempat duduk dan menata peralatan percobaan dan f) peserta didik membersihkan sampah hasil percobaan (peduli lingkungan). 
e. Hasil Pengamatan Efektifitas Belajar

Hasil belajar di siklus II diperoleh nilai rata-rata 78 , nilai tertingginya adalah 100 sedangkan nilai terendahnya adalah 50 . Terdapat 6 peserta didik memperoleh nilai di bawah KKM dan 25 peserta didik yang memperoleh nilai di atas KKM atau diprosentase klasikal sebesar 80,6 \% dengan kriteria tuntas. Visualisasi hasil belajar di siklus II dapat dilihat pada Gambar 3.

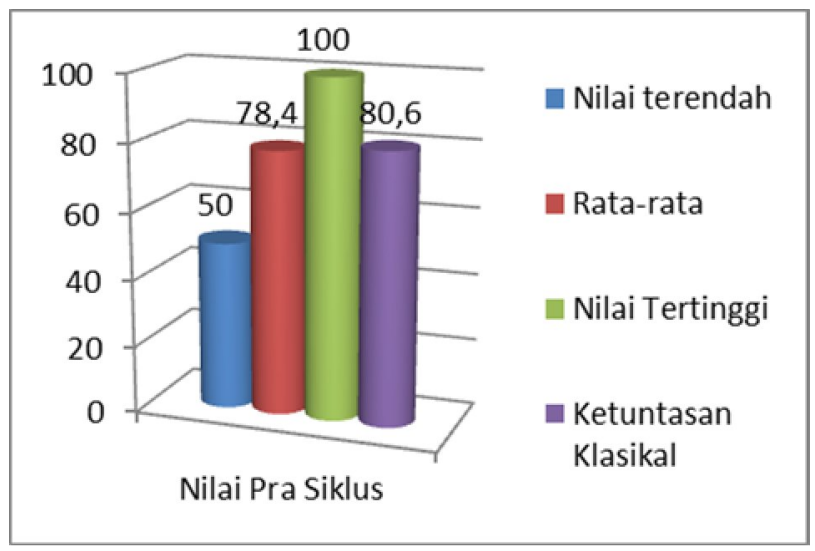

Gambar 3. Hasil belajar Siklus II

\section{f. Hasil Pengamatan Karakter}

Hasil pengamatan karakter pada siklus II diperoleh skor karakter peduli lingkungan adalah 3,50 dengan kriteria Membudaya (MK), karakter rasa ingin tahu dengan skor 3,44 dengan kriteria Membudaya (MK) dan karakter disiplin diperoleh skor 3,50 dengan kriteria Membudaya (MK).

Refleksi (reflecting) Pelaksanaan pembelajaran IPA bervisi SETS dengan pendekatan SAVI terbukti meningkatkan efektifitas hasil belajar dak karakter peduli lingkungan, rasa ingin tahu dan disiplin. Hasil perbandingan efektifitas pembelajaran dengan karate dapat dilihat pada Tabel 4. 
Tabel 4. Perbandingan hasil belajar dan karakterPra siklus, siklus I dengan siklus II

\begin{tabular}{|c|c|c|c|c|c|c|}
\hline \multirow{2}{*}{ Siklus } & \multirow{2}{*}{$\begin{array}{c}\text { Hasil } \\
\text { Belajar }\end{array}$} & \multirow{2}{*}{ Kriteria } & \multicolumn{3}{|c|}{ Karakter } & \multirow{2}{*}{ Kriteria } \\
\hline & & & 1.1 & 1.2 & 1.3 & \\
\hline $\begin{array}{l}\text { Pra } \\
\text { siklus }\end{array}$ & $54,8 \%$ & BT & 2,47 & 2,68 & 2,16 & $\begin{array}{c}\mathrm{MB}, \mathrm{MB}, \\
\mathrm{MT}\end{array}$ \\
\hline Siklus I & $77,4 \%$ & TT & 3,36 & 3,37 & 3,22 & $\begin{array}{c}\text { MK, MK, } \\
\text { MB }\end{array}$ \\
\hline Siklus II & 80.6 & TT & 3,50 & 3,44 & 3,50 & $\begin{array}{c}\mathrm{MK}, \mathrm{MK}, \\
\mathrm{MK}\end{array}$ \\
\hline
\end{tabular}

Keterangan: 1.1 Peduli lingkungan, 1.2 Rasa ingin tahu,, 1.3 Disiplin

Tabel di atas menunjukkan bahwa hasil pembelajaran di siklus II berhasil meningkatkan hasil belajar dan karakter. Adapun penjelasannya adalah sebagai berikut: 1) prosentase klasikal hasil belajar peserta didik sebesar 3,2\% dari skor di siklus I 77, 4\% dan siklus II 80,6\% keduanya dalam kriteria Tuntas (TT), 2) skor karakter peduli lingkungan berhasil meningkat sebesar 0.14 dari skor di siklus I 3,36 menjadi 3,50 yang keduanya dalam kriteria Membudaya (MK), 3) skor karakter rasa ingin tahu meningkat sebesar 0,07 dari skor siklus I 3,37 menjadi 3,44 di siklus II dan keduanya dalam kriteria Membudaya (MK), 4) skor karakter disiplin meningkat sebesar 0,28 dari skor di siklus I 3,22 dengan kriteria Mulai Berkembang (MB) menjadi 3,50 di siklus II k dalam kriteria Membudaya (MK).

\section{Pembahasan}

Penelitian tindakan kelas dilaksanakan di SD Negeri Sadeng 03 UPTD Pendidikan Kecamatan Gunungpati Kota Semarang. Penelitian 16 MAGISTRA - Volume 7 Nomor 1 Oktober 2016 
dilaksanakan dari bulan September hingga November tahun 2012. Langkah awal dalam penelitian ini adalah mencari data kondisi awal peserta didik. Kondisi awal berupa hasil belajar dan karakter. Instrument yang digunakan adalah soal tes, lembar pengamatan dan studi dokumentasi untuk melihat hasil belajar sebelumnya.

Kegiatan penelitian yang terdiri dari dua siklus dilaksanakan di kelas $\mathrm{V}$ dengan materi system pernafasan manusia. Langkah awal adalah dengan mengikuti alur Penelitian Tindakan Kelas yang terdiri dari perencanaan, tindakan, pengamatan dan refleksi. Tahapan perencanaan dimanfaatkan peneliti untuk menyusun instrument penelitian berupa soal tes dan lembar pengamatan karakter dan perangkat pembelajaran yang terdiri dari Silabus, RPP dan LKPD.

Instrument dan perangkat pembelajaran terlebih dahulu divalidasi oleh teman sejawat. Hasil validasi menunjukkan keseluruhan instrument dan perangkat pembelajaran dapat dipergunakan tanpa adalnya revisi. Lembar validasi dapat dilihat pada halaman lampiran.Tahapan tindakan di kedua siklus adalah untuk menguji ke efektifan hasil belajar dan karakter peserta didik.

\section{a. Efektivitas Hasil Belajar}

Efektivitas hasil belajar menunjukkan peningkatan dari pra siklus ke siklus I dan dari siklus I ke siklus II. Peningkatan hasil belajar materi system pernafasan dalam pembelajaran IPA bervisi SETS dengan pendekatan SAVI dapat dilihat pada Tabel 5.

Tabel 5. Peningkatan Hasil Belajar siklus

\begin{tabular}{ccc}
\hline Siklus & Nilai & Ketuntasan \\
\hline
\end{tabular}




\begin{tabular}{lcccc}
\hline & Terendah & $\begin{array}{c}\text { Rata- } \\
\text { rata }\end{array}$ & Tertinggi & (\%) \\
Pra Siklus & 40 & 66 & 90 & 54,8 \\
Siklus I & 50 & 75,2 & 100 & 77,4 \\
Siklus II & 50 & 78,4 & 100 & 80,6 \\
\hline
\end{tabular}

Tabel 6 di atas dapat diketahui bahwa nilai terendah prasiklus adalah 40, Siklus I 50 dan Siklus II 50. Peningkatan dari pra siklus ke siklus I sebesar 10 dan tidak ada peningkatan perolehan nilai terendah dari siklus I ke siklus II. Rata-rata nilai di setiap siklus menunjukkan peningkatan yang signifikan. Rata-rata Pra siklus adalah 66, rata-rata siklus I adalah 75,2 dan rata-rata siklus II adalah 78,4. Peningkatan dari pra siklus ke siklus I sebesar 9,2, dari siklus I ke siklus II sebesar 3,2. Nilai tertinggi pada kegitan di pra siklus adalah 90 sedangkan di siklus I dan siklus II 100. Prosentase ketuntasan klasikal diperoleh dari menghitung 75\% dari jumlah peserta didik yang tuntas belajar. Prasiklus jumlah peserta didik yang tuntas adalah 17 dengan prosentase 54, 8\%. Penilaian hasil belajar pada siklus I jumlah peserta didik yang tuntas belajar adalah 24 dengan prosentase $77,4 \%$, pada siklus II jumlah peserta didik yang tuntas belajar adalah 20 dengan prosentase $80.6 \%$. Peningkatan prosentase dari prasiklus ke siklus I sebesar 22,6\%, sedangkan peningkatan prosentase dari siklus I ke siklus II sebesar 3,2\%. Peningkatan hasil belajar dapat divisualisasikan pada Gambar 4.
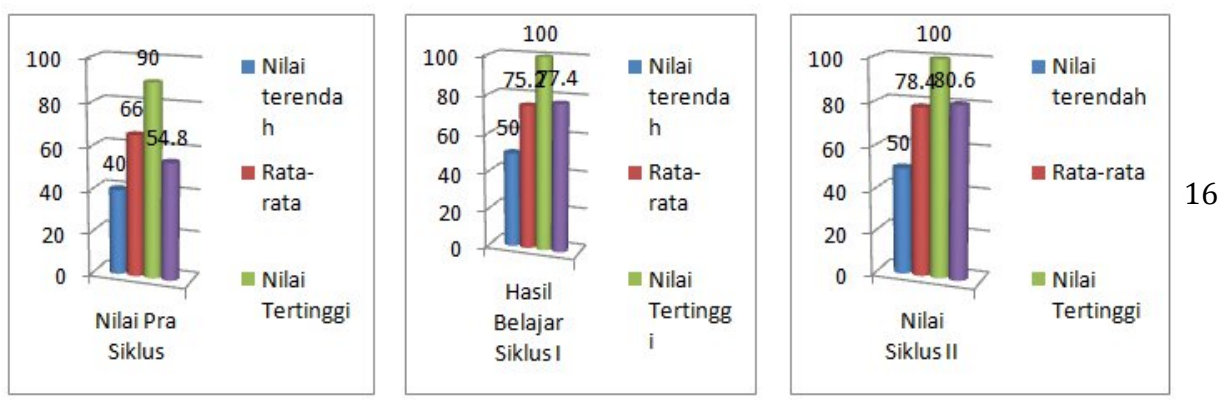
Gambar 4. Peningkatan Hasil Belajar Tiap Siklus

Pembelajaran IPA bervisi SETS dengan pendekatan SAVI berhasil meningkatkan keefektivan belajar peserta didik yaitu dengan ketuntasan kalsikal di siklus II sebesar 80,6\% yang berarti sudah melebihi indikator keberhasilan penelitian pembelajaran IPA materi system pernafasan manusia efektif, yakni hasil belajar kognitif sesuai kriteria ketuntasan belajar minimum klasikal $\geq 75 \%$ di atas nilai KKM yaitu 65 .

\section{b. Karakter}

Penelitian bertujuan memperoleh hasil penilian sikap peduli lingkungan, rasa ingin tahu dan disiplin. hasil penelitian ditunjukkan pada Tabel 6 di bawah ini.

Tabel 6. Skor Karakter Tiap Siklus

\begin{tabular}{ccccc}
\hline \multirow{2}{*}{ Siklus } & \multicolumn{3}{c}{ Skor Karakter } & \multirow{2}{*}{ Kriteria } \\
\cline { 2 - 3 } & $\begin{array}{c}\text { Peduli } \\
\text { Lingkungan }\end{array}$ & $\begin{array}{c}\text { Rasa ingin } \\
\text { tahu }\end{array}$ & Disiplin & \\
Pra Siklus & 2,47 & 2,68 & 2,16 & MT, MB, MT \\
Siklus I & 3,35 & 3,37 & 3,22 & MK, MT, MT \\
Siklus II & 3,5 & 3,44 & 3,5 & MK, MK, MK \\
\hline
\end{tabular}

Tabel 4 menunjukkan adanya peningkatan karakter yang dinilai oleh observer ketika kegiatan pembelajaran. Penjelasan karakter setiap siklus adalah sebagai berikut: 1) Karakter peduli lingkungan pada kegiatan 
pra siklus memperoleh skor 2,47 dengan kriteria Mulai Terlihat (MT), perolehan di siklus II adalah 3,35 dengan kriteria Membudaya (MK) yang berarti terjadi peningkatan 0,88. 2) Karakter rasa ingin tahu pada kegiatan pra siklus memperoleh skor 2,68 dengan kriteria Mulai Terlihat (MT), perolehan di siklus II adalah 3,37 dengan kriteria Membudaya (MK) yang berarti terjadi peningkatan 0,07. 2) Karakter disiplin pada kegiatan pra siklus memperoleh skor 2,16 dengan kriteria Mulai Terlihat (MT), perolehan disiklus II memperoleh skor 3,22 dengan kriteria Mulai Terlihat (MT) yang berarti terjadi peningkatan sebesar 1,06. 3) Karakter disiplin pada pra siklus memperoleh skor 2,16 dengan kriteria Mulai Terlihat (MT), sedangkan di siklus I diperoleh skor 3,22 dengan kriteria Mulai Berkembang (MB) yang berarti terjadi peningkatan sebesar 1,06. Siklus II diperoleh skor 3,5 dengan kriteria Membudaya (MK) yang berarti terjadi peningkatan sebesar 0,28 .

Hasil analisis karakter peduli linkungan dengan skor 3,5, rasa ingin tahu dengan skor 3,44 dan karakter disiplin dengan skor 3,5 sudah melebihi indikator keberhasilan penelitian dengan Skor Akhir Sa 3,25< skor $\leq 4$ ketuntasan klasikal $\geq 75 \%$ pada kriteria membudaya (MK) dengan demikian penelitian berhasil meningkatkan karakter peduli lingkungan, rasa ingin tahu dan disiplin.

\section{SIMPULAN}

Hasil penelitian pembelajaran IPA bervisi SETS dengan pendekatan SAVI efektif dapat meningkatkan hasil belajar peserta didik secara klasikal pada materi system pernafasan manusia. Data hasil penelitian menunjukkan peningkatan prosentase dari kegiatan pra siklus 54,8\% kemudian di siklus I menjadi $77,4 \%$ dan di siklus II prosentase sebesar 80,6\% yang berarti berhasil menjawab hipotesis bahwa hasil belajar peserta didik klasikal pada materi system pernafasan manusia 
menggunakan pembelajaran IPA bervisi SETS dengan pendekatan SAVI $\geq$ 75\% di atas nilai KKM yaitu 65.

Hasil analisis karakter peduli lingkungan dengan skor 3,5, rasa ingin tahu dengan skor 3,44 dan karakter disiplin dengan skor 3,5 sudah melebihi indikator keberhasilan penelitian dengan Skor Akhir Sa 3,25< skor $\leq 4$ ketuntasan klasikal $\geq 75 \%$ pada kriteria membudaya (MK) dengan demikian penelitian berhasil meningkatkan karakter peduli lingkungan, rasa ingin tahu dan disiplin. 


\section{DAFTAR PUSTAKA}

Arikunto, S., Dasar-Dasar Evaluasi Pengajaran. Jakarta: Rineka Cipta, 2006.

Binadja, A., Penerapan Visi SETS Dalam Pengembangan Kurikulum dan Implikasinya, 2006, Makalah. Makalah disajikan pada In House Training, SMA Negeri 4 Semarang. Semarang 10-11 Juli 2006.

Depdiknas. Buku I. Manajemen Peningkatan Mutu Pendidikan Berbasis Sekolah. Jakarta: Depdiknas, 2001.

Hasan, S. H., Pengembangan Pendidikan Budaya dan Karakter Bangsa, Kementrian Pendidikan Nasional Balitbang Puskur, 2010.

Meier, D., The Accelerated Learning Handbook Panduan Kreatif dan Efektif Merancang Program Pendidikan dan Pelatihan, 2002. Transleted by Astuti, Rahmani. 2003. Bandung. Kaifa.

Rusilowati, A., Mitigasi Bencana Alam Bebasis Pembelajaran Kebencanaan Alam Bervisi Science Environment And Society Terintegrasi Dalam Beberapa Mata Pelajaran. Laporan Penelitian. Semarang: Pendidikan Fisika FMIPAUnnes, 2009.

Sulistyorini, S., Pengembangan IPA Sekolah Dasar. Yogyakarta: Tiara Karya, 2007. 